further secular rise of from 0.38 to 0.89 of a scale division. Nothing is said in Joule's paper about the temperatures at which the thermometers had been kept before the readings of the freezing point were taken, but as the later observations-and most of the earlier ones-were made in the winter months, it may perhaps be assumed that the temperatures were nearer $7^{\circ}$ than $30^{\circ}$, and that the actual reading on the scale last winter should be taken as nearer $233^{\circ}$ I than $23^{\circ} 00$. If this is so the total rise of the zero point last winter would be nearer $13.8 \mathrm{r}$ than $13: 30$.

Prof. Schuster states that "with properly annealed thermometers the secular changes are much smaller than the temporary ones," and that is no doubt true for observations extending over a limited time and with such comparatively large variations of temperature as from $7^{\circ}$ to $30^{\circ}$. It may be pointed out, however, that the secular rise since 1879 or 1880 is probably greater than the maximum temporary change recorded by Prof Schuster, and of course the total secular rise is enormously greater.

It may be true that the secular changes of a thermometer grndually vanish, but it must, I think, be conceded, that in the case of Dr. Joule's thermometer it will be a long time before absolute constancy is attained. There can be no doubt that even now, nearly forty-nine years after the first reading was taken, the zero point is still rising, and it does not appear to me to be very improbable that during the next fifty years there may be a further rise of two scale divisions, the amount calculated from the purely empirical formula which I have suggested. SYDNEY YOUNG.

University College, Bristol, February 20.

\section{Foraminifer or Sponge?}

UNDER the above heading in last week's NATURE Dr. Hanitsch briefly draws our attention to Mr. A. Goë;' report on the deep sea organisms procured by Prof. Agassiz in the American tropical Pacific, which he describes as Arenaceous Foraminifera, with the name Neusina Agassizi.

As it was from me that Dr. Hanitsch received the specimens he describes, which I had after a personal conversation on the matter sent him, for his opinion as to their relation to true sponges, I venture to send some further observations on these interesting forms.

Dr. Hanitsch is, I believe, quite right in referring Mr. Goës' Neusina to Prof. Haeckel's Stannophyllum zonarium, as described in his report on the Challenger deep-sea Keratosa. But while admitting my admiration of Prof. Haeckel's wonderful production on the Challenger specimens, I do not agree with him as to their being true Keratose sponges.

My conclusion is based upon the examination of nearly the whole Challenger collection, and in not one species could I find the slightest trace of any of the flagellated chambers characteristic of sponges.

Prof. Haeckel accounts for the absence of this important feature through the bad preservation of the specimens. Yet he describes the most delicate parts of a commensal Hydroid in full, and was able to observe amoboidal cells, and the granulated sarcode bodies peculiar to all bottom living Foraminifera.

If, however, the forms described by Prof. Haeckel prove after all to be true Keratose sponges, the present state of our knowledge does not justify their separation from such recognised genera of Foraminifera, as Masonella, and Syringammina of the late Dr. G. Brady ; Technitella, Haliphysema, and Marsipella of Canon Norman; or Hyperammina palmiformis, described by myself from the Faröe Channel, all which forms have the power of forming siliceous and chitinous skeletons.

Without going into further detail here it will be readily understood that I quite agree with Mr. Goës in piacing these organisms among the Foraminifera, although it would have been better had he given us a clearer and more detailed description of his Neusina.

I had hoped to have published my personal observations on these most interesting organisms, but circumstances have prevented me doing so up to the present.

I for one would be glad if Dr. Hanitsch would give his opinion as to their supposed sponge structure, which he has not done in his previous letter. F. G. PEARCEY,

Late of the Challenger Expedition and Commission.

Owens College Museum, Manchester.

NO. 1217 , vol. 47$]$

\section{Colonial Meteorology.}

ON p. 363 of your last number your reviewer of the "Year-book of the Imperial Institute," after remarking that " climate certainly deserves better treatment," continues :-

"We do not think space would be wasted in giving the mean monthly temperatures and rainfall for the average year and for two extreme years, at a few representative stations in the larger colonies. This information cannot indeed be found in any existing books, but must be worked out from original records, which exist abundantly, and are rarely made available to practical workers."

I am afraid that the reviewer does not always read NATURE, for you, sir, have on several occasions noticed my efforts in this direction, efforts which have gone on uninterruptedly for twenty years. As, now that you have taken the matter up, it is not improbable that some of the funds lavished on the Imperial Institute may be devoted to the subject, and my small organisation be swamped or superseded, I hope that you will, in justice to the directors of the various Colonial observatories who have helped me for so many years, and as some consolation for the entire ignorement of our organisation by your reviewer, allow me to give its history in the fewest words possible.

In 1873 I determined to try to publish monthly a table giving the principal climatic data for each synchronous month at widely spread stations over the entire British Empire. The leading idea was identity, so as to ensure comparability. I therefore prepared some blank forms and sent them with a circular letter to about twenty of our leading Colonial meteorologists. Every one without exception promised to helf, and it says much for colonial climate to add that during the subsequent twenty years not more than five or six of my original correspondents have passed away.

During the period occupied in the transit of my request and of the replies thereto, I wrote a series of short articles pointing out the leading features, and as far as practicable the mean values, for the various stations, so that when we began publishing the monthly values, the departures from the mean could be recognised. These articles and the tables themselves from I 874 to $188 \mathrm{I}$ appeared in The Colonies (subsequently The Colonies and India). When in 1882 that paper passed into other hands, the proprietors declined to publish the tables, and I began to insert them in the Meteorological Magazine, where they have appeared regularly month by month for the subsequent thirteen years. At the close of each year an extra table is given with a summary of the results for the year, and NATURE has often done me the honour of quoting portions of these summaries.

I enclose copy of our last table, and though I know that to reproduce it would be to make a somewhat large demand upon your space, I feel that the work (wholly unpaid, be it remembered) of my Colonial friends during these past twenty years, claims some consideration and some recognition. You will see by the signatures that the authorities are the highest attainable.

\section{2, Camden Square, N.W., February 17.}

$$
\text { G. J. SyMons. }
$$

\section{Ozone.}

With reference to a paragraph in NATURE, p. 373 , on observations of ozone in the atmosphere, and the paucity of observers and records; I may be allowed to state that I have collected sets in the North Atlantic and Pacific Oceans and Mediterranean. These have been taken by officers of the Royal Navy and mercantile marine at sea, and some of the records have heen tabulated, and may be communicated to some society in due course. Moffatt's papers, made by Negretti and Zambra, have been used throughout, so the observations are all uniform and comparable.

Edinburgh, February 19.

W. G. BLACK.

\section{LION-TIGER AND TIGER-LION HYBRIDS.}

THE Council of the Royal Zoological Society of Ireland entertain some hope that it will be possible to produce in their Gardens examples of hybrids or cross-breeds between the two largest species of cat, namely, the lion and tiger.

'I hat such hybrids have been produced is a matter of historical record, and as the writer is particularly inter- 